\title{
PRÁTICAS DA IMAGEM E PRODUÇÃO DE VIDAS: INSURGÊNCIAS CURRICULARES VISUAIS, ESTÉTICAS E CULTURAIS NAS REDES
}

- ALDO VICTORIO FILHO

Universidade do Estado do Rio de Janeiro

RODRIGO TORRES DO NASCIMENTO

Universidade do Estado do Rio de Janeiro

RESUMO Abordando aspectos teóricos da imagem e sua relevância na formação de indivíduos e coletivos, esse artigo pretende contribuir com os estudos da Cultura Visual \& Educação, refletindo sobre criações, trânsito e efeitos de imagens caras a parte da juventude brasileira, nas redes sociais, autoimagem, selfies e de outras ordens. Apoiados em dois populares ídolos juvenis - Inês Brasil e o grupo de funk Bonde das Bonecas, criadores de suas imagens e detentores de notoriedade em meio à precariedade material, contraestética e de insurgência contra padrões imagéticos dominantes -, tomamos a circulação de suas imagens como notável militância visual, visto catalisarem e agregarem a simpatia de muitos jovens que, ao se sentirem representados, reproduzem imagens, falas e performances como afirmação identitária. Modos de ser e de aprender a ser que desafiam a atualização da educação escolar face às produções curriculares confrontadas e contaminadas pelas redes e visualidades.

Palavras-chave: Cultura Visual. Selfies. Juventudes. Escolas. Currículos. Visualidades.

\section{ABSTRACT PRACTICES OF IMAGE AND PRODUCTION OF LIVES: VISUAL, AESTHETIC AND CULTURAL CURRICULUM INSURGENCES IN NETWORKS}

By approaching theoretical aspects of Image and its relevance to the formation of individuals and colectives, this article intends to contribute to the study of Visual Culture and Education, reflecting on creations, traffic and effects of expensive images of the Brazilian youth in social networks, self-image, selfies and in other orders. Supported 
by two popular juvenile idols - Inês Brasil and the Bonde das Bonecas funk group, creators of their images and holders of notoriety amidst material precariousness, counter-aesthetics and insurgency against dominant imagery patterns - we take the circulation of their images as a remarkable visual militancy, as they catalyze and aggregate the sympathy of many young people who, when feeling represented, reproduce images, speeches and performances as an affirmation of identity. Ways of being and learning to be that challenge the updating of school education in face of the curricular productions confronted and contaminated by the networks and visualities.

Keywords: Visual Culture. Selfies. Youths. Schools. Curricula. Visualities.

\section{RESUMEN PRÁCTICAS DE IMAGEN Y PRODUCCIÓN DE VIDAS: INSURGENCIAS CURRICULARES VISUALES, ESTÉTICAS Y CULTURALES EN LAS REDES}

En el marco de los aspectos teóricos de la imagen y su relevancia en la formación de individuos y colectivos, este artículo pretende contribuir con los estudios de la Cultura Visual \& Educación, reflexionando sobre creaciones, tránsito y efectos de imágenes caras a parte de la juventud brasileña en las redes sociales, autoimagen, selfies y otros órdenes. En Brasil y el grupo de funk Bonde das Muñecas, creadores de sus imágenes y poseedores de notoriedad media a la precariedad material, contra-estética e insurgencia contra patrones imagéticos dominantes - tomamos la circulación de sus imágenes como notable militancia ya que catalizan y agregan la simpatía de muchos jóvenes que al sentirse representados reproducen imágenes, discursos y actuaciones como afirmación identitaria. Modos de ser y de aprender a ser que desafian la actualización de la educación escolar frente a las producciones curriculares confrontadas y contaminadas por las redes y visualidades.

Palabras clave: Cultura Visual. Selfies. Juventudes. Escuelas. Visualidades.

Dentre os muitos elementos e presenças imagéticas que interessaram à pesquisa, da qual resulta o presente artigo, o grupo de funk Bonde das Bonecas e a performer e professora de dança Inês Brasil foram escolhidos para referendar a argumentação a respeito da importância de sua arte e de suas pessoas, no universo juvenil contemporâneo, dito desviante ou tradicionalmente insurgente, comumente desqualificado por meio dos termos viado, bicha, sapatão etc. Termos, como logo discutiremos, que são ressignificados em meio à cultura juvenil específica desses grupos apontados e de muitos outros com os 
quais os jovens interagem e se identificam em maior ou menor grau. Convém observar que as juventudes em sua diversidade possuem dimensões complexas. Abrigos identitários transitórios emergem com maior legitimidade do que identidades equivocadamente fixáveis. Conforme Hall, o que fora uma identidade fixada, torna-se uma "celebração móvel", criada e transformada continuamente em relação aos meios e modos pelos quais somos representados ou interpelados nos sistemas culturais que atravessamos. Em outros termos, a identidade não seria definida biologicamente e apenas e tão somente histórica e culturalmente. 0 sujeito assume identidades diferentes em diferentes momentos, identidades que não são unificadas ao redor de um "eu" coerente (HALL, 2005, p. 12-13), como se o jogo identitário fosse conduzido pelas necessidades e oportunidades que enfrentamos e desfrutamos.

O percurso investigativo praticado assume a admiração e o afeto dos jovens sobre os quais refletimos, a partir de seus ídolos. Uns artistas, outros nem tanto, umas verdadeiras celebridades, outros relevantes subcelebridades, esses sujeitos, com suas imagens marcantes e visualidades inusitadas, não poderiam ser preconceituosa e açodadamente descartados face à sua importância em meio aos jovens. Foi preciso conhecê-los e entender suas criações e relação com seus públicos. Inês Brasil e o Bonde das Bonecas destacam-se de forma diversa dos grupos musicais e "Divas Pop", apoiados pelo maquinário e capital da indústria do entretenimento, mas alcançando fama e sucesso por seus próprios meios e redes de admiradores. Meios que se beneficiaram de certa adesão, espontaneidade e admiração, dos que os iam descobrindo. No início de suas aparições, sem qualquer respaldo profissional e comercial, atraíram a atenção e o afeto de milhares de jovens, certamente não apenas pelas qualidades comuns às divas eleitas pelas mídias comerciais, mas, sobretudo, pela maneira de afirmar a liberdade que almejam e possibilitam. A precariedade e a contraestética aplicadas tiveram efeito positivo junto aos grupos que, sob alguns importantes aspectos, se viam representados.

Assim, a aparente e, sob alguns aspectos concreta, precariedade de condições materiais permitiu apenas que Inês Brasil e o Bonde das Bonecas recorressem aos meios alcançáveis, e nada sofisticados, em termos tecnológicos, contudo, de inquietante potência visual e estética. E eles o fizeram com singular inventividade. As condições e os condicionantes que cercaram a vida desses artistas lhes ofereceram, entretanto, larga liberdade na elaboração de suas imagens, tanto do plano visual quanto simbólico. Tal liberdade vai da pronúncia e do sotaque de seus discursos e criações poéticas ou artísticas à criação das suas imagens e falas livres da perícia estética mainstream. Suas performances e demais criações resultam de muitas formas de improvisação, cujas ousadias redundam na apresentação de visualidades singulares que descortinam a parte mais brilhante e doce de suas existências, pois as imagens que realizam são, para o seu público, mais que familiares, para muitos são íntimas dos problemas e anseios de seus interlocutores.

Distinto de qualquer outro momento da história da humanidade, hoje é possível conversar e enviar textos, imagens, músicas, vídeos, de forma instantânea para uma ou várias pessoas de qualquer parte do mundo, mediante o apoio de um aparelho de celular. Os tempos atuais presenciam uma gigantesca e intensa "viralização", ou seja, a circulação contaminante de imagens e de visualidades. O trânsito de imagens via redes de comunicação virtual alcança inimaginável volume, circu- 
lação incontrolável que contém todo tipo de representação visual. Mirzoeff (2015) destaca que, só de selfies, houve, em 2013, na Grã-Bretanha, a divulgação de bilhões de imagens. Em meio à atual configuração da cultura visual, imagens que, há algum tempo seriam consideradas incomuns, circulam junto à novas maneiras de uso e de criação visual. Como exemplificam as imagens dos protagonistas deste estudo, selfies, montagens e imagens de Inês Brasil e do Bonde das Bonecas emergem e circulam, muitas vezes carregadas de derrisão e deboche, oferecendo-se a apropriações diversas e, assim, contribuindo para a emergência e a visibilidade de uma quantidade de jovens que se veem representados e/ou identificados nessas imagens.

É importante, em benefício do melhor entendimento da dimensão ocupada pela imagem no plano virtual, retomar algumas considerações do autor ainda em relação à selfie. Criação e compartilhamento da imagem que se escolhe para si. Mutável, editável, substituível, enfim, livre na inventividade das redes. No capítulo "Selfies e a maioria planetária", Mirzoeff (2015, p. 63) do seu livro "How to see the world", o autor observa que, na atualidade de grandes e intensas transformações, as categorias de identidade estão sendo refeitas e reformuladas. Citando o estudioso da teoria queer, Jack Halberstam, em sua afirmação de que "os tijolos de construção da identidade humana imaginada e cimentada no último século - o que chamamos de gênero, sexo, raça e classe - mudaram tão radicalmente que uma nova vida pode ser vislumbrada no futuro" (HALBERSTAM apud MIRZOEFF, 2015, p. 62), Mirzoeff afirma que o lugar onde podemos perceber estes vislumbres é a selfie. Isto porque, quando as pessoas comuns se produzem e posam da melhor forma que podem para a selfie, elas alcançam momentaneamente o papel de artista-como-herói (MIR-
ZOEFF, 2015). Cada selfie seria uma performance, uma criação artística da sua própria imagem, ou seja, da imagem que desejaria ser vista pelos outros. A selfie, teria adotado, então, a aventada estética tecnologizada do pós-modernismo e adaptada à audiência ilimitada da Internet. Conforme Bauman (2001), o imediatismo instantâneo, ou seja, a superação da resistência do espaço e a liquefação na materialidade dos objetos no trânsito virtual faz com que cada momento pareça ter capacidade infinita; e a capacidade infinita significa que não há limites ao que pode ser extraído de qualquer momento - por mais breve e "fugaz" que seja. A despeito dos aspectos ameaçadores, alertados pelo autor sobre tal panorama, o fato inquestionável é que on-line ou nas novas interações no mundo real com tecnologia, nós experimentamos o avanço e o desdobramento atualizadores da Cultura Visual e o que nos é oferecido em termos de resistência e afirmação.

Efetivamente, nossos corpos habitam e circulam na rede e no mundo, ao mesmo tempo. A despeito dos julgamentos desqualificadores da cultura da performance digital, como desastre estético, e das selfies, como obsessão pela autoimagem, o mais importante a ser também considerado é a sua novidade como movimento não normalizável. Assim como deve ser considerado, então, o poder da imagem de criação livre e circulação ilimitada, igualmente livre de controle censor. Assim, o que por ora poderíamos afirmar com alguma certeza sobre a interação, uso e exploração da rede global pelos jovens, é que ela sempre se modificará de forma frequente e imprevisivel. Esses modos de criação e uso da imagem apresentam formas e caminhos que fatalmente podem desafiar o entendimento das gerações anteriores e levá - las a repensar suas convicções a respeito dos assuntos que os jovens fazem e farão circular na grande rede. 
Imagem 1: Selfie de Inês Brasil.

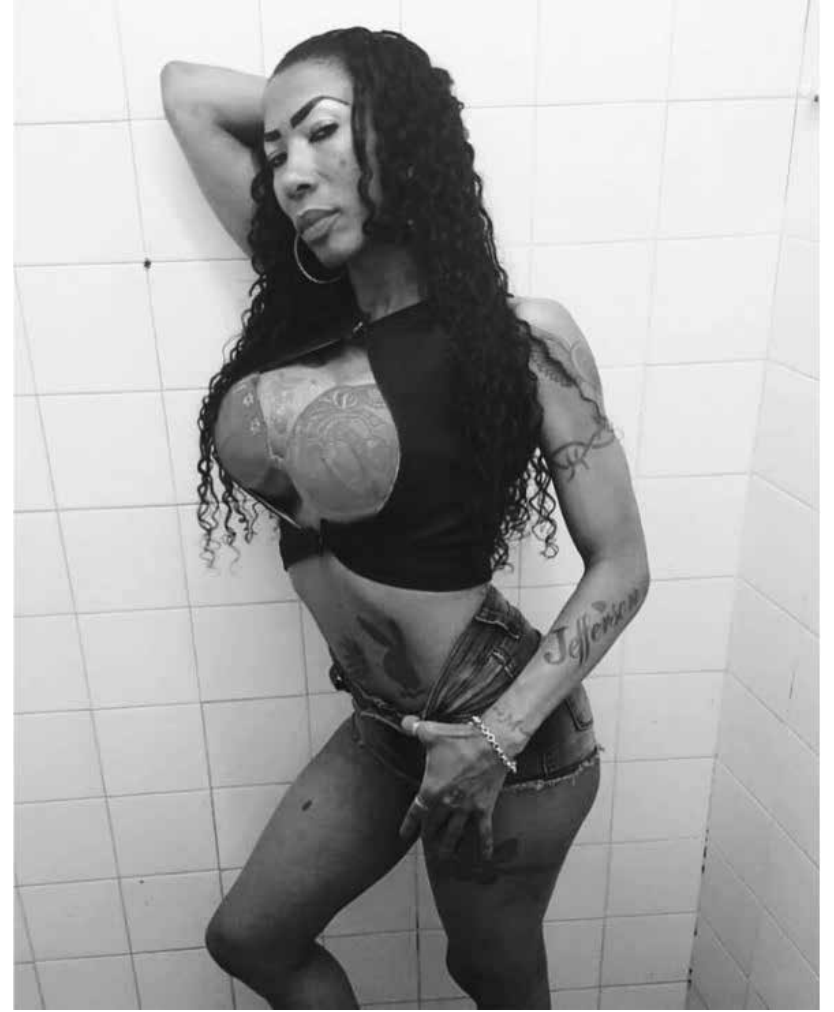

Fonte: Facebook / Inês Brasil.'

As muitas imagens produzidas pelos jovens e lançadas na rede são fontes indispensáveis para a compreensão da atualidade e, sobretudo, das realidades das juventudes. Vídeos capturados na rede e editados domesticamente, memes, ${ }^{2}$ gifs $^{3}$ e selfies são novas formas de conversação visual digital. As selfies, por exemplo, são a primeira forma da nova maioria global lançar-se fora do reduzido espaço do indivíduo. E isso é muito significativo. Conforme os estudos apresentados por Mirzoeff (2015, p. 63), na obra citada, “[...] o fenômeno da 'selfie' começou após o lançamento

1 Disponivel em: <https://www.facebook.com/OficiallnesBrasil/>. Acesso em: 13 jul. 2017.

2 Na internet a expressão meme passou a ser usada para descrever imagens, vídeos, gifs e/ou relacionados que se dissemina nas redes sociais virtuais de forma instantânea. 0 termo faz referência ao conceito de memes, referente à teoria ampla de informações culturais, pensada por Richard Dawkins, em 1976, no livro The selfish gene.

3 Gif: Graphics Interchange Format ou GIF é um formato para intercâmbio de gráficos, no ambiente virtual, é uma imagem de mapa de bits muito usado na web, para imagens fixas ou para animações, tornando-se muito popular na rede, exatamente pela possibilidade de animação de imagens. de câmeras frontais de melhor qualidade com o iPhone 4 em 2010, com outros modelos de telefone seguindo rapidamente". Selfies poderiam agora ser tiradas fora de casa ou usando flash, sem resultar em um borrão de luz dominando a foto, como as fotos tiradas em espelhos, que eram essenciais na rede social Orkut, nos seus tempos áureos de 2004 a 2010. Uma "selfie" é entendida como uma foto de si mesmo (ou incluindo a si mesmo) tirada pelo próprio fotógrafo e fotografado, segurando a câmera no comprimento do braço, ou em sua extensão, com os suportes popularmente chamados "pau-de-selfie", que, distanciando a câmera, permitem um plano visual maior. Um vocabulário visual "padrão" para a "selfie padrão" tem emergido. Elas saem melhor se tiradas de cima com o sujeito olhando para cima, para a câmera. A foto geralmente concentrada no rosto, leva ao risco de registrar uma "duck face", que seria literalmente cara de pato ou mesmo fazendo bico ou "beicinho". Se o autor exagerar e sugar suas bochechas demais, surgirá a inevitável duck face. Essas poses, longe de ferirem ou se importarem com os códigos estéticos tradicionais, que impunham aos retratos aparência de dignidade, beleza ou heroísmo irreais, estão refazendo o autorretrato global. Apesar do nome, a selfie não se reduz ao indivíduo, na verdade refere-se a grupos sociais...

É evidente que a descoberta das possibilidades sempre crescentes da rede e das não menos vertiginosas tecnologias de produção e edição de fotos foram acompanhadas pelo desenvolvimento da atenção e das habilidades no trato com o visual. Quanto mais fácil e instigante se tornou a produção e a circulação de imagens, mais ampliou-se o estímulo à sofisticação e à experimentação de novas formulações visuais. Se um grande número de pessoas ainda é fiel e obediente aos padrões estéticos dominantes, quando se trata da ela- 
boração de suas imagens para objetivos variados, outro grupo, cada vez maior, encontra na rede e no domínio de seus usos um campo de divertida criação e outros aliam esses aspectos com a militância. Assim, a tendência a compartilhar o que antes se dispensaria como "selfies feias" ou selfies não-convencionais é crescente. 0 que uma imagem não condenável aportaria para além da mera inconveniência ou inadequação pode ser lido como sinais claros de insurgência. Uma imagem transgressora tem efeito mais imediato que uma declaração textual, alcança maior pregnância, rejeição ou simpatia. Veicula muitas informações, cuja simultaneidade e articulação efetivam enunciados rápidos e precisos. Na imagem de Inês Brasil, sua indumentária, acessórios, pose, fisicalidade, cabelos, maquiagem, tudo isso configura um discurso forte e combativo. Se ao olhar desavisado e politicamente amodestado parece ser algo reprovável, a esse mesmo olhar a imagem cheia de interrogações afirma ao menos a sua existência. E tal afirmação já é em si um modo de luta em defesa da inexorável diversidade humana e cultural.

Enquanto a exposição das autoimagens, ou selfies aumentava vertiginosamente, certo pânico moral emergia na mídia (AGGER, 2012). Mirzoeff (2015, p. 64) cita, em seu livro, um comentário típico, vindo de um comentarista da CNN, canal a cabo de notícias norte-americano, Roy Peter Clark: "Talvez a conotação da selfie seja egoísta, absorta em si mesmo, narcisista, o centro do universo, um salão de espelhos em que cada reflexo é o de si próprio". Entretanto, a captação da novidade deu-se de outra forma para muitos outros, talvez não menos discutível, como é o exemplo citado da revista Esquire, também norte-americana, na qual o escritor Stephen Marche (2013) declarou que a selfie seria a "masturbação da autoimagem", afirmando, contudo, que isso seria um elogio, pois a realização da selfie é controlada e pro- porciona liberação. Entretanto, tais metáforas distorcem ainda a amplitude do uso e a exploração das redes por meio das imagens. "Narciso passou sua vida olhando para si mesmo, mas ele não liberou uma cópia da sua imagem para que os outros pudessem olhar para ela [...]" (MIRZOEFF, 2015, p. 65).

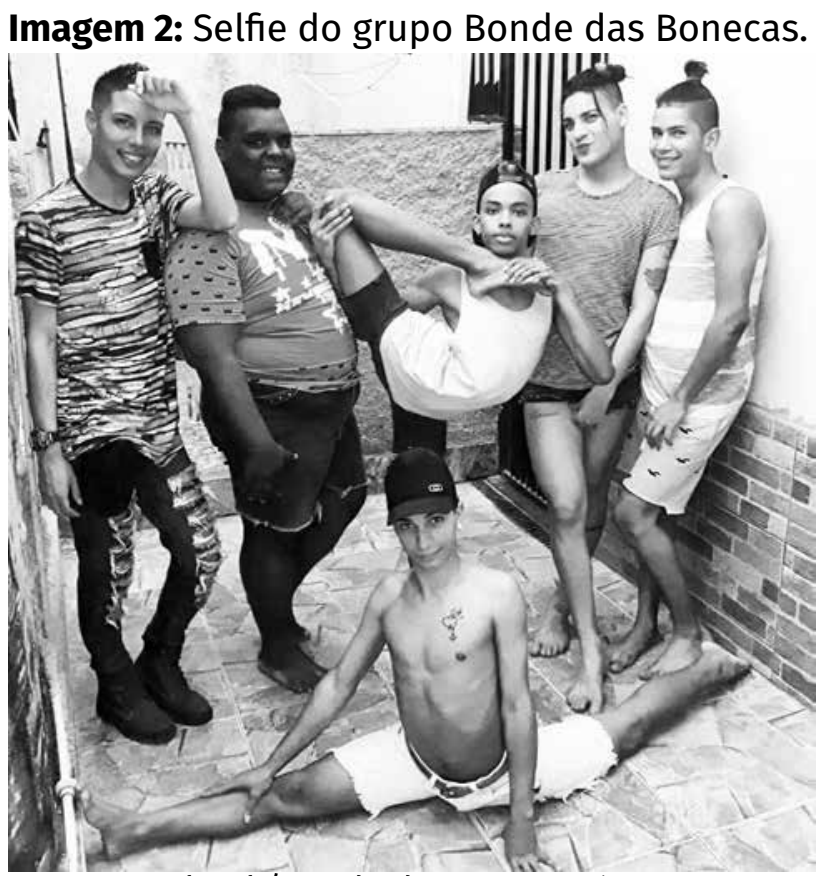

Fonte: Facebook/Bonde das Bonecas. ${ }^{4}$

A imagem de si e de seus ídolos ou coletivos, realizadas no entendimento contemporâneo que articula fotografar e divulgar no mesmo gesto, remetem, portanto, e inexoravelmente ao compartilhamento. E tal prática não poderia ser classificada como masturbação, ou seja, algo prazeroso que acontece na privacidade do indivíduo, visto ser, antes de mais nada, um convite para que os outros curtam, desaprovem, sejam provocados, aproximados, aprendam e reajam. Mas vejam! Ou seja, que considerem o que você fez e participem de uma conversação visual. Conversa com lógica própria que lida com o efêmero, com a celeridade e o imediatismo. Condições ou aspectos ainda considerados negativos, porquanto opostos à tradição da pausa e ritmo da

4 Disponivel em: <https://www.facebook.com/BondeDas-Bonecas-395215143918871/>. Acesso em: 13 jul. 2017. 
tradição dialógica. Entretanto, a circulação e o intercâmbio de imagens, longe de dispensar o diálogo ou suspender a consistência das relações, estimulam a vascularização das redes de contatos interpessoais e propiciam novas trocas e encontros. Como um simples exemplo, podemos observar que, em meio aos comentários a respeito de uma imagem qualquer, relações são iniciadas, pontos de vista discutidos, revistos e embates provocados. Claro que, em se tratando de jovens, os recursos textuais são modulados de acordo com suas práticas de escrita, abreviações, uso de imagens e de símbolos, e muitas gírias, o que torna muitas frases incompreensiveis para quem não pertence às tribos, o que não autoriza a sua desqualificação ou descrédito.

Enfatizando a potência das redes e do panorama no qual nossos protagonistas emergiram e cresceram, destacamos algo grandioso, como os números sugerem. Apenas na Inglaterra, 35 milhões de selfies foram postadas na internet em cada mês do ano de 2013. $\mathrm{Na}$ metade de 2014, o Google afirmou que $93 \mathrm{mi}-$ Ihões de selfies eram postadas mundialmente, a cada dia, mais de 30 bilhões em um ano (MIRZOEFF, 2015).

A pesquisa, a partir do redimensionamento das distâncias entre os pesquisadores e os espaços investigados (VICTORIO FILHO, 2007, p. 108) que desenvolvemos, nos fez observar, algo já suposto e de certa obviedade, ou seja, que as elaborações estéticas, áudio e visuais, ecoam mais forte, ou ao menos mais rápidas e, efetivamente, nas subjetividades dos jovens fãs de Inês Brasil e do Bonde das Bonecas, que discursos racionalizados, sejam conservadores ou não. $O$ efeito imediato do encontro entre sujeitos coletivos e aqueles que os representam se dá prioritariamente, no caso estudado, por meio das imagens e visualidades. Cada detalhe visual é discursivo, aponta um sentido, funde a experiência estética visual com muitas rela- ções e alertas, como toda obra de arte e mesmo aquelas, quando o acontecimento estético se afirma para além dos espaços outorgados da arte (HERNÁNDEZ, 2011, p. 48). Cada vídeo ou foto aporta uma infinidade de indícios e conexões do universo afetivo e existencial particular às sensações e sentimentos que irmanam as multidões de admiradores dos artistas.

No encontro via imagens, há em jogo uma contraestética, ou seja, uma estética que emerge do que os padrões dominantes refutam e condenam ao apagamento - a voz do favelado, a cor do favelado, o corpo da mulher que rompe o recato imposto, a deselegância da pobreza material, a abominação da bicha afeminada, a aparência execrável da prostituta pobre, enfim, tudo o que fere e escapa ao controle do regime estético supostamente referência das classes dominantes. Em nossa pesquisa, constatamos também como os admiradores da Inês Brasil e do Bonde das Bonecas reconhecem, em suas manifestações artísticas, possibilidades concretas de fortalecimento de suas condições inegavelmente insurgentes contra os padrões instituídos. E recorrentemente desfrutam das manifestações dos seus ídolos na rede, para fortalecer suas conversas e posicionamentos, seja por meio do simples compartilhamento de memes, de músicas, vídeos etc., ou da criação e edição de novas mensagens visuais nesses formatos.

\section{Se me atacar, eu vou atacar ${ }^{5}$}

Com a intensa viralização das produções artísticas do Bonde das Bonecas, nos deparamos em seus perfis e páginas na internet, com grande e expressiva quantidade de curtidas, comentários e compartilhamentos, feitos por variado perfil de pessoas, crianças, jovens, adultos, homens, mulheres, declaradamente heterossexuais, cisgênero e LGBT. As reações

5 Frase célebre de Inês Brasil, pronunciada por ela em um de seus vídeos. 
manifestadas são diversas, o que mostra que uma parcela de seus espectadores não aprova necessariamente suas produções. A opinião sobre o trabalho do Bonde das Bonecas e de Inês Brasil é diversificada, mesmo entre os jovens LGBT. Muitos espectadores gays desaprovam suas experiências artísticas, dentre esses, expressivo número é contra "dar pinta" ou ser afeminado e vê Inês Brasil como um "exagero", um tanto quanto desmoralizante. Estes preferem se associar ao padrão heteronormativo, ${ }^{6}$ ainda socialmente dominante. Tal escolha estratégica, na maioria dos casos, se justifica como forma de ser "aceito" mais facilmente e, portanto, não sofrer discriminação ou se colocar em risco de agressões e escárnios. Creem, efetivamente, que a tática do disfarce ou camuflagem seria mais eficaz que assumir a rejeição e lidar favoravelmente com ela.

Talvez por isso não aceitem e condenem os jovens cujos comportamentos são radicalmente opostos à dissimulação da condição cultural, realidade ou desejo. Ou seja, rejeitam os jovens que preferem expressar o que desejam e defender a configuração que desejam dar às suas existências. Certamente, o problema também se refere à imagem, precisamente à visualidade como efeito de construção coletiva das imagens que envolvem o visto e o que vê. O problema, portanto, é profundo e avança para além dos limites fluidos de uma redutora territorialidade gay. 0 que estaria em jogo seria o ato de ser humano entre humanos, e ser humano como autocriação, a despeito dos embates entre as várias formas de masculinidade, que, conforme Connel (1995, p. 198-190), seria uma composição de imagem complexa e contraditória, inseparável das relações sociais e dos corpos. Assim, no mesmo contexto histó-

6 Concepção de que as pessoas possuem gêneros distintos e complementares (um binarismo entre homem e mulher) com papéis naturais na sociedade, vendo a heterossexualidade como única orientação sexual possivel e normal. rico, são observáveis diversas masculinidades e todas as formas de masculinidade sofrem contradições e conflitos. Nessa complexa movimentação das masculinidades, sobressai determinado modelo de masculinidade constituído e deflagrado a partir de marcas de masculinidade periféricas, na medida em que o que compõe e consolida o gênero são as relações de poder, para além das tensões de dominação características da relação homem/mulher. Entre as masculinidades e a constituição de seu modelo hegemônico, há também ações de marginalização, identificação e hierarquização, de tal modo que a predominância de um padrão de masculinidade é transitória, pois os padrões estão sempre sujeitos a resistências e questionamentos, ao longo do tempo.

Entretanto, a "contrarrejeição", central nas produções de finalidade artística, estimula pensar sobre o panorama virtual e a emergência de obras, as quais, independentes de seleções, validações e demais instrumentos de legitimação da obra de arte tradicional, alcançam um público notável, em número e diversidade, e nele provocam e estimulam mudanças e ações. Público que, embora varie da efusiva admiração à dura rejeição, se comunica e interage em meio à insurgência das imagens na rede.

0 embate de visualidades divergentes, insurgentes e empoderadoras, no âmbito público das redes sociais, é uma excelente fonte para o entendimento de problemas centrais na sociedade brasileira. Isto porque tal embate exemplifica o preconceito, a homofobia, o racismo e a transfobia que as "minorias"7 sexuais, raciais e de gênero, sofrem ao assumirem suas existências e alçar espaços de protagonismo, seja cantando em um vídeo ou posando para uma foto.

7 Grupos sociais que sofrem processos de estigmatização e discriminação, resultando em diversas formas de desigualdade ou exclusão social, mesmo quando constituem a maioria numérica de determinada população. 
Imagem 3: Selfie de Adrian Brasil para a campanha "Sou/Curto afeminado".

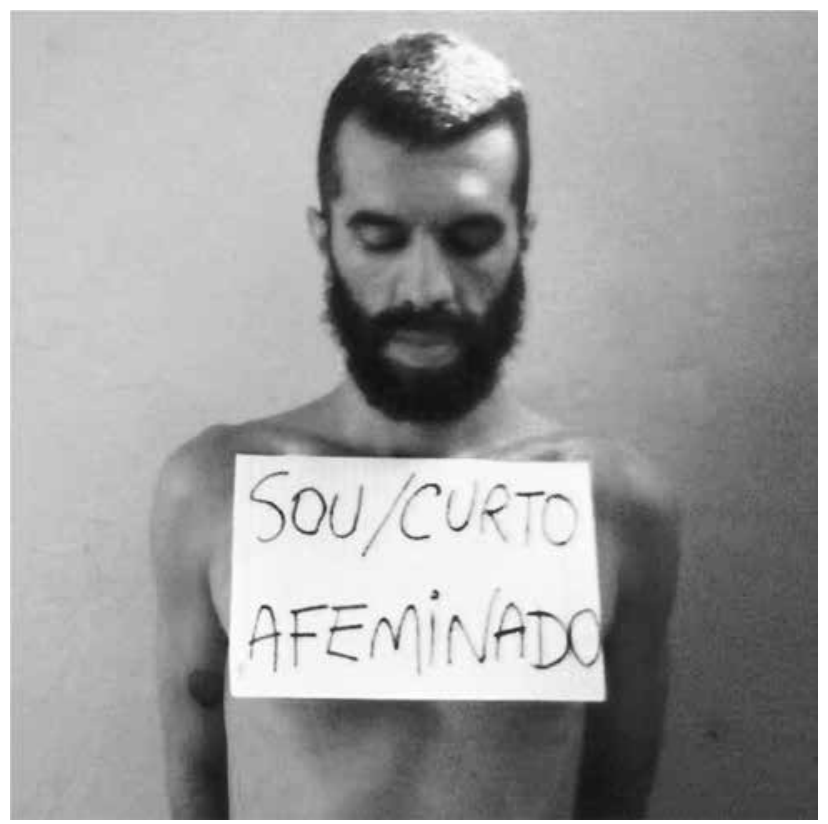

Fonte: Facebook / Sou/Curto Afeminado. ${ }^{8}$

Um dos fatores mais importantes que alicerçam a relevância, aqui constatada, do trabalho dos jovens do Bonde das Bonecas e da cantora e professora de dança Inês Brasil é o exemplo que oferecem de audácia, coragem, possibilidade de sucesso e de afirmação identitária. A despeito dos interditos tradicionais à imagem da pobreza, à homossexualidade e à negritude, as suas obras, fruto de autores que trazem nos seus corpos a interseccionalidade dos fatores apontados, dãose por meio de criação estética, cuja potência lhes permite vencer, mesmo que provisória ou oportuna e parcialmente, o conservadorismo estruturante da sociedade brasileira e incentivar seu público à ampliação de seus territórios políticos, poéticos e existenciais. Convém observar que o público desses artistas guarda certa heterogeneidade. Embora a maioria dos "curtidores" pertença às camadas sociais desfavorecidas, a apreciação da arte desfaz fronteiras de toda ordem e opor-

8 Disponivel em: $<$ https://www.facebook.com/SouCurto-Afeminado-1489496857938694/>. Acesso em: 13 jul. 2017. tuniza intercâmbios diversos entre os admiradores das mesmas obras e/ou dos mesmos artistas.

Em um dos vídeos mais famosos do Bonde das Bonecas no YouTube, por exemplo, o número de pessoas que "não curtiram" o vídeo é um pouco superior ao número de pessoas que "curtiram" o trabalho. Mesmo esse número não sendo apurado com exatidão, haja vista que nem todas as mais de 3 milhões de pessoas que assistiram à performance do grupo participaram da "pesquisa" feita pelo YouTube, os números significam um dado a ser considerado, já que demonstram que uma possivel maioria das pessoas que assistiram ao trabalho dos jovens funkeiros não gostou do gênero ou da performance avaliada, pois, a obra alcançou os olhares reprovadores.

As chamadas "minorias" sexuais são, hoje, mais visiveis do que há algum tempo, e, por consequência, torna-se mais acirrada a luta entre essas minorias e os grupos conservadores. Esse embate, que merece especial atenção de toda a sociedade, e em especial dos estudiosos/as culturais e educadores/as, se torna ainda mais complexo se pensarmos que o grande desafio não consiste, apenas, em assumir que as posições de gênero e sexuais se multiplicaram e escaparam dos esquemas binários, mas também em admitir que as fronteiras vêm sendo constantemente atravessadas e que o lugar social no qual alguns sujeitos vivem é exatamente a fronteira (LOURO, 2001, p. 541). Assim, as insurgências aos padrões, cada vez mais enfatizadas nas redes por meio das imagens que produzem e fazem circular, evidenciam a profundidade e a grandeza do desafio. Afirma a autora que esses "embates de visualidades" se tornaram mais acirrados hoje, porque as "minorias" sexuais e de gênero são mais visiveis do que antes e o contexto virtual é onde essa visibilidade e esse embate se dá em grande parte do tempo. 
Os choques virtuais entre as visualidades acirram-se em vários momentos, já que a "liberdade" na rede, frequentemente catártica, permite que os jovens não se contenham na manifestação de seus desejos e vontades. Os jovens, na maioria das vezes, interagem nas redes sociais sem a preocupação com possíveis represálias. Isso faz com que, ao mesmo tempo, a internet seja entendida como canal e espaço libertadores. Contudo, em muitos momentos, se torna um campo aberto no qual preconceitos, discursos de ódio, machismo, homofobia e transfobia, circulam com frequência e violência assustadoras. A transgressão aos critérios básicos de convivência e respeito à diversidade acontece sem acanhamento tanto por meio da invasão de páginas específicas quanto na criação de espaços virtuais dedicados a ataques contra minorias. Esse panorama preocupante é devido à impunidade e às raras consequências negativas trazidas a quem comete esse tipo de delito, o que leva ao aumento das manifestações preconceituosas de toda ordem.

Entretanto, as insurgências sobre as quais nos detemos não se reduzem à suposta imobilidade e passividade das imagens. As imagens veiculadas catalisam e agregam indivíduos vítimas ou alvo de agressões e exclusões e, assim, novas formas de organização são oportunizadas, gestadas e articuladas para contrapor o ódio e a violência. A imagem visual ganha contornos de arma na luta virtual. A criação de páginas, campanhas ou grupos no Facebook, para servirem de espaço aglutinador da juventude dissidente, interseccional e sempre insurgente, tem sido recorrente. Existem hoje diversos territórios virtuais que servem tanto para a divulgação de fotos e vídeos de determinadas tribos juvenis, dedicados a enaltecer suas beleza e diversidade, assim como para incentivar e unir jovens dispostos a disputar espaços e enfrentar seus opositores.
As diversas formas que a juventude viada, trans, sapata tem encontrado para se fortalecer e se defender são verdadeiras obras de arte dentro do universo virtual. Suas campanhas utilizam inusitadas criações na busca de seus objetivos, dentre os quais está o reconhecimento e o respeito. Suas formas de resistência e luta recorrem a doses de derrisão esvaziadoras da estética e cultura outorgadas. São sempre bem-humoradas sem comprometer a seriedade da luta engajada, de forma que seus memes, gifs, fotos, vídeos etc. são viralizados e ampliam expressivamente o número de seus companheiros, simpatizantes e demais.

Os jovens, sobretudo os que formam as tribos que destacamos, têm conseguido, através da rede e de suas próprias maneiras de luta, gerir espaços cada vez mais autênticos de combate à opressão de formas suaves e aglutinadoras, nas quais as suas imagens e as de seus ídolos se tornam escudos, afagos e espadas. Suas visualidades, libertas de culpa, pudor ou constrangimento, são formas de promover seu orgulho dentro da rede e favorecer outros jovens que anseiam a emancipação dos cerceamentos que acometem sobretudo os indivíduos que se veem diferentes e ao mesmo tempo solitários em sua suposta singularidade. Encontrar, portanto, alguém que enalteça a condição ou característica que nos aflige e condena, é, efetivamente, vital para a sobrevivência e a afirmação social.

Todos os grupos das ditas "minorias" têm explorado modos de se conectar e se autovalorizar, seja pela publicação de fotos, vídeos, imagens de seus ídolos ou por meio de suas próprias performances. A "viralização" de personagens que assumem a positividade de suas características e diferenças estéticas contra -hegemônicas se torna cada vez mais frequente e vital. 


\section{E nas escolas?}

Esse trabalho, sob muitos aspectos, decorre de pesquisa na confluência da Educação e da Arte. Buscando entender parte das insurgências juvenis das minorias, por meio da observação das formas, dos meios e dos recursos que as novas gerações lançam mão para o fortalecimento e a realização das suas formações, escolhemos, como afirmamos, um exemplo que demonstra a potência dos currículos independentes das escolas. Assim, Inês Brasil e tantos outros artistas de produção contra-hegemônica oferecem sua imagem/obra como substância útil à criação de saberes, por sua vez, necessários às performances de muitos jovens, performances que amalgamam ações individuais e coletivas, indiscriminadamente, como se caracterizam as movimentações tribais da contemporaneidade (MAFFESOLI, 2006).

A escola, como conceito generalista, é facilmente associada a denominações como disciplina, obediência, ordenação, comportamento, progresso, autocontrole, hierarquia etc., termos quase opostos e muitas vezes antagônicos a instinto, intuição, improviso, paixão. Ou seja, aspectos crepusculares ou noturnos que contrastam com o sentido iluminista da educação formal generalizada, que, sob entendimento reducionista, priorizaria a mente em detrimento do corpo. Razão versus instintos, humores, paixão e desejo, uma impossivel oposição de parte do corpo com o seu todo. Reconhecendo que a escola universal não existe, afirmamos a impossibilidade de reduzir a singularidade dos inumeráveis espaços e tempos escolares a uma única ideia de escola. Entretanto, o peso do termo emblemático, "a escola", assombra e cerceia a licitude da atualização de muitas das práticas escolares e contamina a formação das futuras gerações de professores.

o currículo realizado, como nutriente e sistema circulatório de todo o corpo escolar, dá- se pelo conjunto de ações e acontecimentos que propiciam experiências efetivas (LARROSA BONDÍA, 2002), sem os quais não há modificação, não há partilha e ampliação de saberes, ou seja, o mínimo sucesso da agenda educacional. Contudo, sob a sombra de uma escola impossivel, germinam e florescem outras escolas marginais à oficial, que fortalece a mente e disciplina o corpo. Habitando o mesmo espaço e tempo da escola oficialmente legitimada, ações dão-se na incondicionalidade da rebeldia do cotidiano (OLIVEIRA, 2003), evidenciando que currículo é o que aporta ao, viabiliza o, produz e efetiva algum e todo o conhecimento, inclusive o de si, seja por meio de alguma teatralizada ou ritualizada operação da razão ou na surpresa desconcertante do escândalo da insurgência do corpo desvencilhado de uniformes e uniformizações. o currículo realiza-se e se produz na segurança da disciplinarização do mundo e no asselvajamento catártico do corpo, na subversão da linguagem ou na precisão técnica do discurso, porém, nunca em apenas uma só das aparentes polaridades.

Por isso, nessas impossiveis e impermeáveis polarizações, o corpo é o coringa inconveniente e imprescindivel e sua gestualidade, sua pulsação e imagem, dispensam a palavra e suspendem o sentido. 0 corpo aprende inteiro, com a cor da sua pele, o volume de sua carne, a textura de seus pelos, a intensidade do seu desejo, e com as demais partes de seu todo, como a voluptuosidade e o acanhamento de suas belezas. 0 que o corpo vale e oferece é a presença, e uma das personagens de referência da pesquisa, Inês Brasil, oferece aos seus admiradores exatamente a matéria incontrolável de um corpo em movimento, eufórico e abusado, junto ao qual, as palavras se desbotam ou tomam outro poder, incorporadas pelos jovens que as reconfiguram em outras órbitas. Os sentidos das palavras de Inês Brasil são inseparáveis das suas visualidades. Em última 
instância, uma dica e desafio aos professores que pretendem o diálogo produtivo com as novas gerações.

A educação formal, independente do grau de participação nos processos formativos, não domina incólume a formação dos jovens e futuros cidadãos. É sabido que outros elementos interagem, atravessam, enviesam, impregnam, deslocam e reorientam o que se aprende nas escolas. Em outros termos, a busca ou a aceitação de outros alicerces formativos, fora do repertório autorizado dos currículos oficiais, expõe a força das culturas dos estudantes, culturas juvenis (PAIS, 1993) em disputa pela afirmação de formas de existir, o que implica na involuntária interferência e intervenção no aparato escolar. 0 princípio da escola que ainda deseja ensinar tudo a todos a um só tempo e ao mesmo tempo, que se desmonta diante das culturas permanentemente dinamizadas pelos jovens, se ajusta às verdades de seu tempo, mesmo que ainda subterraneamente, por meio da indisciplina, desobediência e transgressão. Tais aspectos têm alçado relevância na formação dos indivíduos, pois denotam não mais apenas o delito, mas o fortalecimento da subjetividade, os pertencimentos identitários, a afirmação das diferenças, o desenvolvimento dos corpos coletivos, o avanço das redes de subjetividade e, sobretudo, a presença assumida e positivada do corpo encarnado.

Buscando alguns dos princípios escolares, embora sempre questionada, convém reiterar, que a intenção de muitas das investidas curriculares é aplicar o padrão hegemônico de saberes a ser aprendido pelos estudantes exitosos. O grau de sucesso e de rendimento escolar dá-se em função da aproximação que cada estudante alcança do referido padrão, constituído de um modelo de vocabulário, pela incorporação de certezas, a aceitação de valores morais e estéticos, a subordinação a uma referência específica de corpo, de sexualidade, de afeto, de saúde, ou seja, modelo e padrão de existência, que exclui a participação do estudante, ou seja, do que ele sente e elabora a respeito disso tudo. Trata-se da ação de uma máquina curricular de ordenação política. Entretanto, esse modelo legitimador da pretensa formação exitosa se esvai diante da circulação célere de elementos radicalmente estranhos aos currículos formais. São elementos virais complexos demais para serem digeridos pela formalidade institucional, entretanto de manejo e jogo fácil e íntimo dos jovens que frequentam as escolas e delas fazem escolas-encontro, uma ressignificação da instituição, via intercâmbios realizados na prática cotidiana, sempre produtiva e efervescente, na qual fulguram outros modos de acontecimentos não menos consistentes, do ponto de vista curricular.

Dentre os aludidos elementos virais, está o universo das imagens visuais, das potências estéticas, para além do acervo curricular autorizado, ou seja, da Arte e Ciências outorgadas. o plano visual que apontamos é sobretudo o universo das imagens corpo, das imagens transgressoras e até abjetas. Imagens estranhas à escola, quando reduzida à ideia de um currículo frio e anódino, mas, nada estranhas à escola-insubordinada, a dos currículos criados e porosos, a dos coletivos que se destinam e por eles são atravessados e enriquecidos.

As imagens, centrais a um dos campos teóricos nos quais apoiamos nossa pesquisa e este artigo, ou seja, a Cultura Visual, se mostram cada vez mais relevantes na Educação contemporânea, pois são territórios e instrumentos dos quais partem o diálogo e a elucidação das visualidades que, por sua vez, envolvem todos os processos e meios formativos. Entendidas as visualidades como o jogo entre a produção e o consumo de imagens, instâncias intercambiantes na medida em que toda percepção visual implica na fabricação do 
que é visto por aquele que o vê. As imagens visuais são, nessa perspectiva, propostas ou enunciados iniciais abertos à participação dos olhares interlocutores que, ao encontrá-las, as ampliam, degeneram, substituem, desenvolvem etc., em conformidade com as histórias, condições, interesses e demais contextos dos envolvidos.

\section{Considerações finais}

A intensa proliferação de imagens e autoimagens revolucionou agudamente a paisagem visual global. Através das redes sociais, na internet, é possivel que um jovem morador das favelas do complexo do Alemão no Rio de Janeiro divulgue seu trabalho fotográfico e seja encontrado por olhares em todo o mundo. Tal concreta possibilidade, a todo tempo explorada, permite diálogos visuais que superam as barreiras das línguas e caracterizam as redes como um poderoso veículo não mais de mera divulgação, mas campo de estímulo à criação e exploração, para fins diversos e incontroláveis, de obras e canais audiovisuais. Cantoras, cantores, grupos musicais, seitas, facções, artistas de todas as linguagens, além de uma

\section{Referências}

AGGER, Ben. Oversharing: presentations of self in the internet age. Londres: Routledge, 2012.

BAUMAN, Zygmunt. Modernidade líquida. Tradução de Plínio Dentzien. Rio de Janeiro: Zahar, 2001.

BONDE DAS BONECAS. Facebook do Bonde das Bonecas. Disponivel em: $\leq$ https://www.facebook.com/ Bonde-Das-Bonecas-395215143918871/>. Acesso em: 13 jul. 2017.

BOURRIAUD, Nicolas. Estética relacional. Tradução de Denise Bottmann. Buenos Aires: Adriana Hidalgo, 2006.

CONNEL, Robert W. Políticas da masculinidade. Tradução de Tomaz Tadeu da Silva. Educação \& Rea- infinidade de criadores de imagens, ganham notoriedade por meio de suas imagens, obras ou músicas publicadas no YouTube, Facebook, Twitter, Instagram, Snapchat etc., e, via a visibilidade global, reconfiguram o planeta e, consequentemente, instigam a atualização das escolas e da formação de seus profissionais.

Com o Bonde das Bonecas e Inês Brasil, os indivíduos e suas obras que, tradicionalmente, seriam relegados ao desprezo ou apenas considerados como brincadeiras ou inapropriados à reprodução, se tornam atores e instrumentos de luta na qual exploram a fama e a popularidade em benefício do respeito às suas existências. Respeito não só no meio virtual, mas nas suas comunidades de origem e mesmo em outros espaços nos quais estes autores insurgentes nem sempre transitam pessoalmente. Visto que as suas performances alcançam territórios diversos e são curtidas por milhares de pessoas de todas as classes e rankings econômicos. É justamente essa dimensão que evidencia a potência estética relacional e a poética colaborativa (BOURRIAUD, 2006, p. 75) liberta de padrões e políticas estético-culturais que interessa à pesquisa destacar e, nos seus limites, contribuir com oportunas elucidações.

lidade, n. 20, v. 2, p. 185-206, 1995. Disponível em: <http://seer.ufrgs.br/index.php/educacaoerealidade/article/view/71725>. Acesso em: 01 abr. 2017.

DAWKINS, Richard. The selfish gene. Oxford: Oxford University Press, 1976.

HALL, Stuart. A identidade cultural na pós-modernidade. Tradução de Tomaz Tadeu da Silva e Guacira Lopes Louro. Rio de Janeiro: DP\&A, 2005.

HERNÁNDEZ, Fernando. A cultura visual como um convite à deslocalização do olhar e ao reposicionamento do sujeito. In: MARTINS, Raimundo; TOURINHO, Irene. (Orgs). Educação da cultura visual: conceitos e contextos. Santa Maria: Editora UFSM, 2011. p. 31-50. 
INÊS BRASIL. Facebook da Inês Brasil. Disponivel em: <https://www.facebook.com/OficiallnesBrasil >. Acesso em: 13 jul. 2017.

LARROSA BONDÍA, Jorge. Notas sobre a experiência e o saber de experiência. Revista Brasileira de Educação, n. 19, p. 20-28, 2002. Disponivel em: <http:// www.scielo.br/pdf/rbedu/n19/n19a02.pdf>. Acesso em: 13 jul. 2017.

LOURO, Guacira Lopes. Teoria queer: uma política pós-identitária para a educação. Revista de Estudos Feministas, Florianópolis, v. 9, n. 2, p. 541-553, 2001. Disponivel em: <http://www.scielo.br/pdf/ ref/v9n2/8639.pdf>. Acesso em: 13 jul. 2017.

MAFFESOLI, Michel. 0 tempo das tribos: o declínio do individualismo. Tradução de Maria de Lourdes Menezes. Rio de Janeiro: Forense, 2006.

MARCHE, Stephen. Sorry, your selfie isn't Art. Esquire, 2013. Disponivel em: <http://www.esquire.com/ entertainment/a23557/selfies-arent-art/>. Acesso em: 13 jul. 2017.

MIRZOEFF, Nicholas. How to see the world: an introduction to images, from self-portraits to selfies, maps to movies, and more. Nova lorque: Basic Books, 2015.

OLIVEIRA, Inês Barbosa de. Currículos praticados entre a regulação e a emancipação. Rio de Janeiro: DP\&A, 2003.

PAIS, José Machado. Culturas juvenis. Lisboa: INCM, Imprensa Nacional Casa da Moeda, 1993.

VICTORIO FILHO, Aldo. Pesquisar o cotidiano é criar metodologias. Educação e sociedade, Campinas, v. 28 , n. 98 , p. $97-110,2007$. Disponivel em: <http:// www.scielo.br/pdf/es/v28n98/a06v2898.pdf>. Acesso em: 13 jul. 2017.

Recebido em: 10.08.2017

Aprovado em: 30.10 .2017

Aldo Victorio Filho é Doutor em Educação pelo programa de pós-graduação em Educação da Universidade do Estado do Rio de Janeiro (UERJ). Professor Associado do Instituto de Artes, docente dos programas de pós-graduação em Artes (PPGARTES) e de Educação (PROPED) da UERJ, professor visitante da Faculdade de Belas Artes da Universidade de Barcelona.e-mail: avictorio@gmail.com

Endereço: Rua Hadock Lobo, 224/401. Tijuca, Rio de Janeiro, RJ. Cep 20260-142. Tel.: (21) 99159-1873

Rodrigo Torres do Nascimento é Bacharel e Licenciado em Artes Visuais pela Universidade do Estado do Rio de Janeiro (UERJ) e mestre em Artes e Cultura Contemporânea pelo programa de pós-graduação em Artes (PPGARTES) da UERJ. e-mail:torresnrodrigo@gmail.com

Endereço: Rua Srg. Jorge Silvares de Souza, 22. Parque São Vicente, Belford Roxo, RJ. Cep 26178-300. Tel.: (21) 98124-3632. 